\title{
A FORMALIZAÇÃO DO MICROEMPREENDEDOR INDIVIDUAL (MEI) NO MUNICÍPIO DE NOVA OLÍMPIA/MT.
}

\author{
Fernanda de Lima Araújo Silva ${ }^{1}$ \\ Marcelo Evandro Alves ${ }^{2}$
}

\section{RESUMO}

O estudo teve por objetivo averiguar a adesão do Microempreendedor Individual (MEI) no município de Nova Olímpia-MT, e quais benefícios o reflexo da formalização lhes trará. O procedimento metodológico deu-se através de pesquisa de campo, o questionário foi aplicado a 39 empreendedores individuais formalizados pela figura jurídica do MEI. O referencial teórico abordou os conceitos de economia informal, setor informal e suas características; atividade empreendedora do MEI, como é feita a formalização, e as vantagens e desvantagens de ser um microempreendedor individual. Conclui-se que os empreendedores formalizados representam aproximadamente $15 \%$ dos 262 trabalhadores que atuam de maneira informal no município. Em sua totalidade os entrevistados afirmam que com a regularização os pequenos negócios tendem a crescer e se desenvolver, onde o acesso a serviços bancários - crédito foi indicado como o principal benefício na execução da atividade após a formalização. Alguns dos empreendedores contam com auxílio de colaborador na execução de sua atividade, no entanto, apenas $30 \%$ efetivaram o registro em carteira de seus colaboradores, demonstrando que a Lei Complementar 128/08, lei federal que criou a figura jurídica do MEI é alternativa viável para quem deseja estabilidade e segurança futura.

Palavras-chave: Formalização; Benefícios; Microempreendedor Individual.

\section{INTRODUÇÃO}

A informalidade surge em razão do comprometimento do emprego formal, da perda do dinamismo econômico, insuficiência de criação de empregos e a substituição destes por inovações tecnológicas. Que passa a existir com o objetivo de gerar emprego e renda para uma massa da população que se encontra exclusa. (SILVA, et al, 2010)

Para Silva, et al (2010), os efeitos do desemprego não se restringem aos aspectos econômicos, como a perda de rendimento, mas também ocasiona problemas sociais, psicológicos e físicos o que contribui para a exclusão do trabalhador. As pessoas que não encontram trabalho buscam outras maneiras de garantir a sua sobrevivência, bem como a de sua família. Logo, a informalidade prevalece como principal alternativa, para o desenvolvimento de meios de sobrevivência. (SILVA, 2008)

\footnotetext{
${ }^{1}$ Acadêmico do curso de Ciências Contábeis da UNEMAT - Campus de Tangará da Serra, fernanda.lasilva@gmail.com

${ }^{2}$ Professor do Departamento de Ciências da UNEMAT - Campus de Tangará da Serra, marcelo.evandro@unemat.br
} 
A Lei Complementar $\mathrm{n}^{\circ} .128$, de 19 de dezembro de 2008, instituiu a figura jurídica do Microempreendedor Individual (MEI), que veio beneficiar milhares de empreendedores informais, dando-lhes a oportunidade de formalizar seu negócio de maneira simples e rápida, reduzindo a burocracia e altos custos para se constituir uma empresa.

Considera-se MEI o empresário individual a que se refere o art. 966 da Lei nº 10.406, de 10 de janeiro de 2002 - Código Civil, que tenha auferido receita bruta no ano calendário anterior de até $\mathrm{R} \$ 36.000,00$ (trinta e seis mil reais), não ter participações em outras empresas como sócio, ser optante pelo Simples Nacional e que pode ter apenas um empregado contratado que receba um salário mínimo ou piso da categoria. (BRASIL, 2009)

O problema desta pesquisa foi: Quais os reflexos da formalização do microempreendedor individual para o desenvolvimento dos pequenos negócios?

A hipótese levantada para responder ao problema foi: H1 - A figura jurídica do microempreendedor individual é uma alternativa desburocratizante para o exercício de pequenas atividades?

O objetivo geral desta pesquisa consiste em averiguar a adesão do Microempreendedor Individual no município de Nova Olímpia-MT, e quais benefícios o reflexo da formalização lhes trará.

Quanto aos objetivos específicos procurou-se: Identificar o perfil socioeconômico dos empreendedores optantes pelo MEI no município de Nova Olímpia/MT; Realizar pesquisa através de questionário como forma de analisar quais os ramos de atividade que aderiram ao MEI no município.

A importância de se fazer este trabalho está centralizada no fato do empreendedor adotar a informalidade, em muitos casos, como forma de se esquivar dos impostos, taxas e contribuições exigidas pelos fiscos Federal, Estadual e Municipal. Neste contexto, surge o microempreendedor individual como forma de incentivo fiscal, trazendo novas oportunidades e condições especiais para que o trabalhador conhecido como informal possa se regularizar de forma menos burocrática, e tornar-se empresário, gozando de benefícios como: direito a aposentaria, isenção de taxa para registro da empresa, redução da carga tributária, acesso a serviços bancários, possibilidade para vender para órgãos públicos, apoio técnico do SEBRAE na organização do negócio, possibilidade de crescimento como empreendedor e segurança jurídica, pois é amparado pela Lei Complementar $n^{\circ} .128$ de 19 de Dezembro de 2008. 
Através dos dados obtidos na pesquisa pode-se identificar se os empreendedores estão aderindo ao microempreendedor individual, se são conhecedores e se usufruem dos benefícios amparados pela LC 128/08, assim como também suas obrigações. De maneira que, com a formalização, o empreendedor individual estará contribuindo para o desenvolvimento socioeconômico do município e do país. Através do recolhimento de sua contribuição mensal, que num primeiro momento pode não ser tão significativa, pois os 39 (trinta e nove) empreendedores formalizados representam aproximadamente 15\% (quinze por cento) dos 262 (duzentos e sessenta e dois) trabalhadores que atuam de maneira informal, e também pelo fato de ser uma cidade pequena, mas que pode aumentar gradativamente com a adesão de mais trabalhadores.

\section{REFERENCIAL TEÓRICO}

\subsection{Setor Informal e Economia Informal}

Conforme Theodoro (2000), o termo setor informal, aparece inicialmente em meados dos anos 70 criado no seio da Organização Internacional do Trabalho (OIT). O conceito de setor informal surge como um novo instrumento explicativo para um velho fenômeno: a existência de atividades econômicas de baixa produtividade que se desenvolvem a margem da legislação.

[...] a abordagem em termos de setor informal está fortemente associada a uma perspectiva de intervenção, por meio de políticas e programas de apoio levados a cabo inicialmente pelos governos e agências oficiais internacionais - a própria OIT, mas também o Banco Mundial e BID. Surge assim uma nova vertente da ação do Estado. (THEODORO, 2000, p. 7)

Segundo Hirata (2007), a compreensão do setor informal no Brasil se dá pela sua expansão em meados dos anos 1950 até o início de 1980 por meio da industrialização, quando houve uma intensa migração de trabalhadores do campo para a cidade. A não absorção de grande parte dos migrantes oriundos da área rural gera a formação de excedente mão-de-obra.

O fenômeno da informalidade vem crescendo nos últimos anos, e representa objeto de preocupação para os países de terceiro mundo, pela presença significativa de mão-de-obra e a dimensão da pobreza. A desqualificação da mão-de-obra de boa parte da população se traduz em baixos salários e rendimentos, considerando-se as unidades familiares. $\mathrm{O}$ setor informal apresenta uma grande heterogeneidade por absorver várias formas de produção e também de trabalhadores. As pessoas que não encontram trabalho buscam outras maneiras de garantir a sua sobrevivência, bem como a de sua família. Logo, a informalidade prevalece como 
principal alternativa, para o desenvolvimento de meios de sobrevivência. (OLIVEIRA, 1990 apud VIANNA, 2006; SILVA, 2008; SILVA, 2002).

Assim, Fontes (2003 apud SILVA, 2009 p. 65) afirma que "a inserção na atividade econômica com microempresários ou por conta própria tem sido um dos principais meios dos trabalhadores conseguirem seu sustento frente à queda do emprego formal no Brasil".

Segundo Hugon (1997 apud SILVA, 2002, p. 23), em termos conceituais, o setor informal pode ser entendido por

Unidades econômicas que produzem bens e serviços e que trabalham em pequena escala, com baixo nível de organização e uma tênue divisão entre trabalho e capital, relações de trabalho que cobrem estreitamente as relações de parentesco, relações pessoais, sociais, relações muito mais ocasionais do que permanentes.

A economia informal é característica de fenômenos distintos, tais como: evasão e sonegação fiscal, terceirização, microempresas, comércio de rua ou ambulante, contratação ilegal de trabalhadores assalariados nativos ou migrantes, trabalho em domicilio, etc., ou seja, são atividades, trabalhos e rendas realizadas desconsiderando regras expressas em leis e procedimentos padrão. $\mathrm{O}$ seu crescimento se dá principalmente, devido às depressões cíclicas das atividades econômicas, que provocam redução no mercado de trabalho formal, levando o trabalhador à condição de subemprego, contribuindo para o aumento do trabalho autônomo. (CACCIAMALI, 2000; SILVA, 2002)

Quanto ao perfil dos trabalhadores, na visão de Cacciamali (2000)

É uma forma de trabalho que se estende através de indivíduos motivados por dificuldades de reemprego, ou de ingresso no mercado de trabalho, ou que se encontram inativos em famílias com renda familiar baixa, podem ser aposentados que auferem pensões insuficientes, ou até podem ser indivíduos que optaram por essa forma de inserção diante das dificuldades de se adaptarem em trabalhos assalariados.

Para Cacciamali (2000), além das diferenças de renda provocadas pelos desempenhos e características dos diferentes ramos de atividade, não se deve deixar de observar conjuntos de trabalhadores por conta própria de baixa renda que, em virtude de suas habilidades e do mercado em que participam apropriam-se de rendimentos maiores do que se estivessem empregados com carteira registrada. A renda desses trabalhadores depende principalmente de sua ocupação e da renda de sua clientela que é formada em sua maioria por assalariados. Dessa forma, o nível de atividade, o emprego e os ganhos dependem essencialmente da massa de salários dos empregados formais e informais. Quanto maior for a demanda pelos produtos ou serviços oferecidos pelos trabalhadores por conta própria, maior será também a sua renda. 
Dados do IBGE (2003), através da pesquisa Economia Informal Urbana - ECINF confirmam que existiam neste período no Brasil mais de 10,525 milhões de pequenas empresas não agrícolas com até 5 empregados, das quais 98\%, ou seja, 10,335 milhões pertenciam ao setor informal, e ocupavam 13,860 milhões de pessoas. Com relação à pesquisa anterior, em 1997, o número de pequenas empresas aumentou 10\%, sendo que 9\% correspondem a empresas do setor informal, o que significa pouco aumento na formalização das empresas.

Tabela 1 - Empresas não agrícolas com até 5 empregados e Empresas do setor informal, segundo os grupos de atividade - Brasil - 2003

\begin{tabular}{|c|c|c|c|c|}
\hline & \multicolumn{2}{|c|}{$\begin{array}{l}\text { Empresas não agrícolas com } \\
\text { até } 5 \text { empregados }\end{array}$} & \multicolumn{2}{|c|}{$\begin{array}{l}\text { Empresas do Setor } \\
\text { Informal }\end{array}$} \\
\hline & & $(\%)$ & & $(\%)$ \\
\hline Total & 10.525 .954 & 100,00 & 10.335 .962 & 100,00 \\
\hline Indústrias de Transformação e Extrativa & 1.652 .597 & 15,70 & 1.630 .580 & 15,80 \\
\hline Construção Civil & 1.812 .185 & 17,20 & 1.808 .840 & 17,50 \\
\hline Comércio e Reparação & 3.505 .441 & 33,30 & 3.403 .804 & 32,90 \\
\hline Serviços de Alojamentos e Alimentação & 729.078 & 6,90 & 719.107 & 7,00 \\
\hline Transporte, Armazenagem e Comunicações & 837.297 & 8,00 & 831.421 & 8,00 \\
\hline $\begin{array}{l}\text { Atividades Imobiliárias, Aluguéis e Serviços } \\
\text { Prestados às Empresas }\end{array}$ & 684.663 & 6,50 & 655.467 & 6,30 \\
\hline Educação, Saúde e Serviços Sociais & 351.742 & 3,30 & 341.135 & 3,30 \\
\hline Outros Serviços, Sociais e Pessoais & 829.776 & 7,90 & 823.751 & 8,00 \\
\hline Outras Atividades & 35.355 & 0,30 & 34.036 & 0,30 \\
\hline Atividades mal definidas & 87.821 & 0,80 & 87.821 & 0,80 \\
\hline
\end{tabular}

Fonte: IBGE, Diretoria de Pesquisas, Coordenação de Trabalho e Rendimento, Pesquisa Economia Informal Urbana 2003

Segundo o IBGE (2003), “quanto ao funcionamento dos empreendimentos, a pesquisa registrou que $65 \%$ desenvolviam sua atividade produtiva somente fora do domicílio; $27 \%$ exclusivamente no domicílio do proprietário e $8 \%$ no domicílio do proprietário e fora dele $[\ldots] "$.

Um censo econômico realizado em Nova Olímpia, pela Secretaria Estadual de Planejamento (SEPLAN) em 2006, apresentou um levantamento das empresas formais e 
informais existentes no município. Sendo que dos 553 estabelecimentos existentes, um total 312 estabelecimentos, ou seja, 56,4\% são formais - legalmente registradas, e 241 estabelecimentos o que representa $43,6 \%$ são informais - sem registros. (SEPLAN, 2006)

Dos setores da economia, o setor comércio é o que detém o maior número de empresas na informalidade, atingindo um percentual de 54,3\%, seguido de $35 \%$ do setor indústria e 31,6\% do setor serviços. (SEPLAN, 2006)

\subsection{O Microempreendedor Individual}

Os trabalhadores informais no Brasil são muito heterogêneos. Alguns indivíduos ingressam na informalidade por opção, outros por necessidade. O histórico familiar e a preocupação com a qualidade de vida, o levam a procurar essa forma de inserção no mercado de trabalho, em busca de liberdade de ação, trabalhar e controlar seu próprio negócio, jornada de trabalho flexível, entre outros fatores que contribuem para essa oportunidade. (HIRATA, 2007)

No entanto, os pequenos empreendedores encontram um desafio a vencer, que é gerir o seu próprio negócio de modo que ele evolua, com uma baixa escolaridade e sem conhecer as ferramentas de gestão e de administração da produção, o que ocasiona o não controle das contas do negócio. Portanto, o conhecimento prático torna-se grande aliado para aqueles menos instruídos a ingressarem no mundo do trabalho. (SILVA, 2009)

Conforme Chiavenato (2006) são características do espírito empreendedor: necessidade de realização, disposição para assumir riscos e autoconfiança. O empreendedor é a pessoa que consegue fazer as coisas acontecerem, pois é dotado de sensibilidade para negócios, tino financeiro, ou seja, prudência para lidar com finanças e capacidade de identificar oportunidades.

Como forma de incentivo, surge a Lei Complementar $n^{\circ}$. 128, de 19/12/2008, que criou condições especiais para que o trabalhador conhecido como informal, possa se legalizar e tornar-se um Microempreendedor Individual. Considera-se MEI o empresário individual a que se refere o art. 966 da Lei $n^{\circ}$. 10.406, de 10 de janeiro de 2002 - Código Civil, que tenha auferido receita bruta, no ano calendário anterior, de até $\mathrm{R} \$ 36.000,00$, não ter participações em outras empresas como sócio, ser optante pelo Simples Nacional, e que pode ter apenas um empregado contratado que receba um salário mínimo ou piso da categoria. (BRASIL, 2008;

BRASIL, 2009) 


\subsubsection{Formalização do Microempreendedor Individual}

A Lei Complementar $\mathrm{n}^{\circ}$. 128, de 19/12/2008, traz muitas vantagens, uma delas é a desburocratização na hora de formalizar o pequeno negócio. A formalização do empreendedor individual é feita exclusivamente pela internet no Portal do Empreendedor, no endereço eletrônico http://www.portaldoempreendedor.gov.br gratuitamente, ou seja, o ato de formalização está isento de todas as tarifas. Após o cadastramento o empreendedor recebe o Cadastro Nacional da Pessoa Jurídica - CNPJ e o número de inscrição na Junta Comercial. (BRASIL, 2009)

O custo após a formalização compõe:

Para a Previdência: R\$ 59,95 que corresponde a $11 \%$ do salário mínimo que é reajustado a cada ano; Para o Estado: $\mathrm{R} \$ 1,00$ fixo por mês se a atividade desenvolvida for comércio ou indústria; Para o Município: R \$ 5,00 fixos por mês se a atividade desenvolvida for a prestação de serviços. O pagamento se dá por meio de um documento chamado DAS - Documento de arrecadação do Simples Nacional, que é gerado pela internet, com vencimento todo dia 20 de cada mês. (BRASIL, 2009)

No entanto, a Medida Provisória 529, convertida na Lei 12.470, diminui a carga tributária do MEI, ao alterar a alíquota de contribuição à previdência social de $11 \%$ para 5\% sobre o salário mínimo, ou seja, passará a pagar o valor de $\mathrm{R}$ \$27,25 (vinte e sete reais e vinte e cinco centavos) para a previdência. $\mathrm{O}$ objetivo é ampliar os incentivos à formalização. A Medida Provisória passou a produzir efeitos em $1^{\mathrm{o}}$ de Maio do ano vigente. Para fins previdenciários a contribuição de $11 \%$ e agora a de 5\%, permite apenas o direito a aposentadoria por idade. Caso o MEI, queira aposentar-se por tempo de contribuição, ele deve pagar a complementação, ou seja, a diferença entre o percentual pago e o percentual de $20 \%$ sobre o valor do salário mínimo, que após a vigência da MP passou a ser de 15\%. (BRASIL, 2011)

As atividades que podem ser enquadradas pelo Microempreendedor Individual correspondem a aproximadamente 430 (quatrocentos e trinta) ocupações, o objetivo é atingir o público-alvo pretendido pelo MEI, que são aquelas oriundas de atividade por conta própria, urbana e de baixa renda, como por exemplo: artesão, cabeleireiro, carpinteiro, comerciante de roupas, cosméticos, entre outros. No contexto, da Resolução 58 encontram-se todas as atividades que podem ser exercidas pelo MEI. (BRASIL, 2008)

A lei prevê a contratação de até um empregado com remuneração de até um salário mínimo ou piso da categoria. O Microempreendedor Individual deve reter do empregado 8\% do seu salário para contribuição à previdência social, o recolhimento a título de FGTS que é 
de $8 \%$, mais $3 \%$ a título de Contribuição Patronal Previdenciária - CPP. (SANTOS e FREITAS, 2009)

A meta nacional para 2011 estabelecida pelo governo federal e pelas instituições de apoio a formalização era de 1,5 milhão de microempreendedores individuais. A meta foi alcançada quatro meses antes do fim do ano, isso significa que as formalizações avançam em todo o país e cada vez mais trabalhadores estão buscando sair da informalidade. (SEBRAE, 2011)

\title{
2.2.2 Obrigações do Microempreendedor Individual
}

O Microempreendedor Individual, esta dispensado da emissão de nota fiscal para consumidor final pessoa física, no entanto, nas operações com pessoa jurídica, ele pode emitir Nota Fiscal Avulsa - desde que esteja prevista na legislação estadual e/ou municipal. Também estará dispensado de contabilidade, não precisa escriturar nenhum livro. Deve somente guardar as notas fiscais de compras, os documentos do empregado contratado, e os canhotos das notas fiscais que emitir, bem como, fazer um relatório de suas receitas mensais, para a emissão da Declaração Anual do Simples Nacional - Microempreendedor Individual DASN-SIMEI, que deve ser enviada a cada ano. (BRASIL, 2008; BRASIL, 2009)

\subsubsection{Vantagens e Desvantagens}

Acerca das vantagens, Santos e Freitas (2009, p. 7), afirmam que

\begin{abstract}
Essa nova lei (Lei Complementar 128) traz um grande benefício tanto para os microempreendedores como para a economia brasileira de um modo geral: a formalização legal desses profissionais. Através desse processo, eles adquirem direitos importantes como a qualificação de segurado do INSS, o acesso ao crédito, o direito de participar de licitações públicas e a possibilidade de negociar com as demais empresas de forma transparente, sem a menor preocupação com a atuação do fisco sobre sua atividade, uma vez que aderiu à legalidade. É sem dúvida um grande passo para que amanhã, esses microempreendedores se tornem sócios de uma microempresa e isso se torne um círculo de crescimento econômico para as comunidades e para o Brasil.
\end{abstract}

O Portal do empreendedor apresenta algumas vantagens e benefícios tais como: cobertura previdenciária, ausência de burocracia, isenção de taxas para o registro da empresa, contratação de um funcionário com menor custo, acesso a serviços bancários - inclusive crédito, redução da carga tributária, controles muito simplificados, possibilidade de vender para órgãos públicos, possibilidade de crescimento como empreendedor, segurança jurídica, visto que é amparado pela LC 128/08.

Está em análise um Projeto de lei que beneficiará as Micro e Pequenas empresas, inclusive o Microempreendedor Individual. Entre as medidas a serem aprovadas, está previsto 
a ampliação da receita bruta anual do MEI de $\mathrm{R} \$ 36.000,00$ (trinta e seis mil reais) para $\mathrm{R} \$$ 60.000,00 (sessenta mil reais). Institui também várias simplificações para o segmento, como alteração e fechamento do negócio via internet e a qualquer momento. Também está prevista a suspensão da declaração anual do Simples Nacional, sendo que os empreendedores passarão a informar seus dados mensalmente, o que dispensará a necessidade da declaração anual. Se aprovado no Senado as medidas entrarão em vigor a partir de 2012. (SEBRAE, 2011; CRCMT, 2011)

Segundo Fernandes, Maciel e Sossai (2011), as poucas desvantagens destacadas não se equiparam com os pontos positivos oferecidos pela nova legislação. Umas das desvantagens são as vedações legais para se optar pelos valores fixos mensais de tributos abrangidos pelo Simples Nacional.

Estarão vedados a optar pelo SIMEI: aqueles que têm suas atividades tributadas pela lei complementar $n^{\circ} 123 / 2006$, salvo aquelas com autorização relativa a exercício de atividade isolada pelo comitê Gestor e aqueles que possuírem mais de um estabelecimento, que participam de outras empresas como titular, sócio ou administrador ou que contrate empregado, exceto se possuir um único empregado que receba exclusivamente um salário mínimo ou o piso salarial da categoria. (FERNANDES, MACIEL e SOSSAI, 2011, p. 11)

Conforme Brasil (2008), a pessoa que estiver enquadrada na LC 128/08 não pode ultrapassar o limite de $\mathrm{R} \$ 36.000,00$ anual. Se o faturamento for superior a este valor, pode ocorrer duas situações:

A Primeira: o faturamento foi maior que $36.000,00$, porém não ultrapassou R $\$$
$43.200,00$. Nesse caso o seu empreendimento é incluído no sistema do SIMPLES
NACIONAL, na categoria de microempresa, a partir de janeiro do ano seguinte ao
ano em que o faturamento excedeu os R $\$ 36.000,00$. A partir daí o seu pagamento
passará a ser de um percentual do faturamento por mês, $4 \%$ se for comércio, $4,5 \%$ se
for indústria e $6 \%$ se for prestador de serviço. O valor do excesso deverá ser
acrescentado ao faturamento do mês de janeiro e os tributos serão pagos juntamente
com o DAS referente àquele mês. A Segunda: o faturamento foi superior a R $\$$
$43.200,00$. Nesse caso o enquadramento no SIMPLES NACIONAL é retroativo e o
recolhimento sobre o faturamento, conforme explicado na Primeira Situação passa a
ser feito no mesmo ano em que ocorreu o excesso no faturamento, COM acréscimos
de juros e multa. Por isso, recomenda-se que o empreendedor, ao perceber que seu
faturamento no ano será maior que R $\$ 43.200,00$, inicie imediatamente o cálculo e o
pagamento dos tributos acessando diretamente o Portal do SIMPLES NACIONAL,
no endereço www.receita.fazenda.gov.br.

Conforme Fernandes, Maciel e Sossai (2011, p. 12), "além dessa desvantagem, o benefício fiscal obtido a partir da Lei Complementar $n^{\circ} .128$, de 19 de dezembro de 2008, é destinado apenas ao empreendedor e não à empresa que o contrata, ou seja, o empreendedor individual não poderá realizar cessão ou locação de mão-de-obra". 


\section{METODOLOGIA}

Segundo Both e Siqueira (2004, p. 48), "é preciso que ocorra a delimitação do tema a ser pesquisado, visto a necessidade de independência daquilo que será investigado em função de descriminá-los de outros temas afins".

A metodologia indica um plano para conduzir a investigação, por isso se faz necessário a abordagem de tipologias de delineamentos de pesquisa, agrupadas em três categorias: pesquisa quanto aos objetivos; pesquisa quanto aos procedimentos; pesquisa quanto a abordagem do problema. (BEUREN, 2004).

O universo de estudo é composto por empreendedores que são formalizados pela figura jurídica do microempreendedor individual, atuantes no município de Nova Olímpia MT.

A tipologia desta pesquisa quanto aos objetivos é exploratória e descritiva, pois objetiva averiguar a adesão do Microempreendedor Individual no município de Nova Olímpia-MT, e quais benefícios o reflexo da formalização lhes trará.

A pesquisa exploratória é aplicada em um tema pouco conhecido, é realizada em ambientes onde o fenômeno ainda não foi estudado, visa esclarecer o problema para que o mesmo possa se tornar mais explícito e familiar ao pesquisador. (VERGARA, 1997; GIL, 2010). O estudo descritivo permite ao pesquisador a obtenção de uma melhor compreensão do comportamento de diversos fatores e elementos que influenciam determinado fenômeno. (OLIVEIRA, 2001)

Os procedimentos metodológicos adotados para a coleta de dados foram: o método de pesquisa bibliográfica, consulta de livros, artigos científicos e internet, para constituir o referencial teórico e recolher informações acerca do tema de estudo; o método de pesquisa de campo, com o intuito de buscar informação diretamente com a população pesquisada, através de questionário misto, contendo 18 perguntas, sendo as mesmas fechadas e abertas, que continham informações descritivas - dados sobre: renda, idade, escolaridade, etnia, sexo, características do empreendimento e o método de pesquisa documental que consiste na relação de empreendedores individuais formalizados, fornecida pela prefeitura municipal.

Conforme Oliveira (2001, p. 119), “a pesquisa bibliográfica tem por finalidade conhecer as diferentes formas de contribuição que se realizaram sobre determinado assunto ou fenômeno". 
Para Oliveira (2003, p. 66), “a pesquisa de campo permite o acúmulo de conhecimento sobre determinado aspecto da realidade, conhecimento esse que pode ser comprovado e utilizado por outros pesquisadores".

Pesquisa documental é uma forma para se coletar dados através de documentos conservados no interior de órgãos públicos e privados de qualquer natureza. Documento é qualquer objeto constituído por um texto escrito e, papel, mas estão se tornando cada vez mais frequentes os documentos eletrônicos, disponíveis sobre os mais diversos formatos. (VERGARA, 1997; GIL, 2010)

Quanto à abordagem do problema foi utilizado o método quantitativo, que de acordo com Beuren (2004, p. 92), "a abordagem quantitativa caracteriza-se pelo emprego de instrumentos estatísticos, tanto na coleta como no tratamento dos dados".

A coleta de dados se deu no mês de Outubro de 2011, no qual foram aplicados os questionários ao público alvo, que são os empreendedores individuais formalizados pelo que estabelece a LC 128/08 que é a Lei do microempreendedor individual. Foram aplicados 39 (trinta e nove) questionários e todos foram utilizados para a discussão dos resultados.

\section{RESULTADOS E DISCUSSÕES}

Diante dos conceitos anteriormente apresentados sobre a informalidade e a nova modalidade jurídica, o microempreendedor individual, e a metodologia apresentada nesta pesquisa para a coleta de dados, apresenta-se a seguir a discussão dos resultados obtidos, através dos questionamentos aplicados à população amostral que são 39 (trinta e nove) empreendedores formalizados pelo MEI atuantes no município de Nova Olímpia/MT.

\subsection{Perfil dos entrevistados}

Quanto ao gênero dos empreendedores individuais entrevistados em Nova Olímpia, foram constatados os resultados auferidos na pesquisa, conforme Figura 1. 


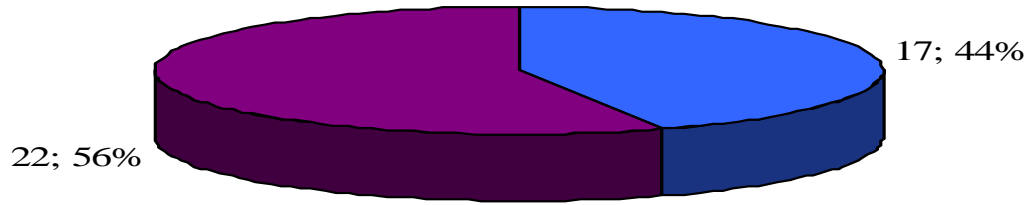

$\square$ Masculino

Feminino

Figura 1 - Gênero dos microempreendedores individuais em Nova Olímpia - MT, período de outubro/2011. FONTE: Dados da pesquisa.

Na Figura 1, verifica-se que do total da amostra pesquisada, 56\% (cinquenta e seis por cento) são do sexo feminino e $44 \%$ (quarenta e quatro por cento) são do sexo masculino. Nota-se que o número de mulheres é superior ao de homens, o que significa a presença feminina conquistando seu espaço, e auxiliando na geração de renda familiar.

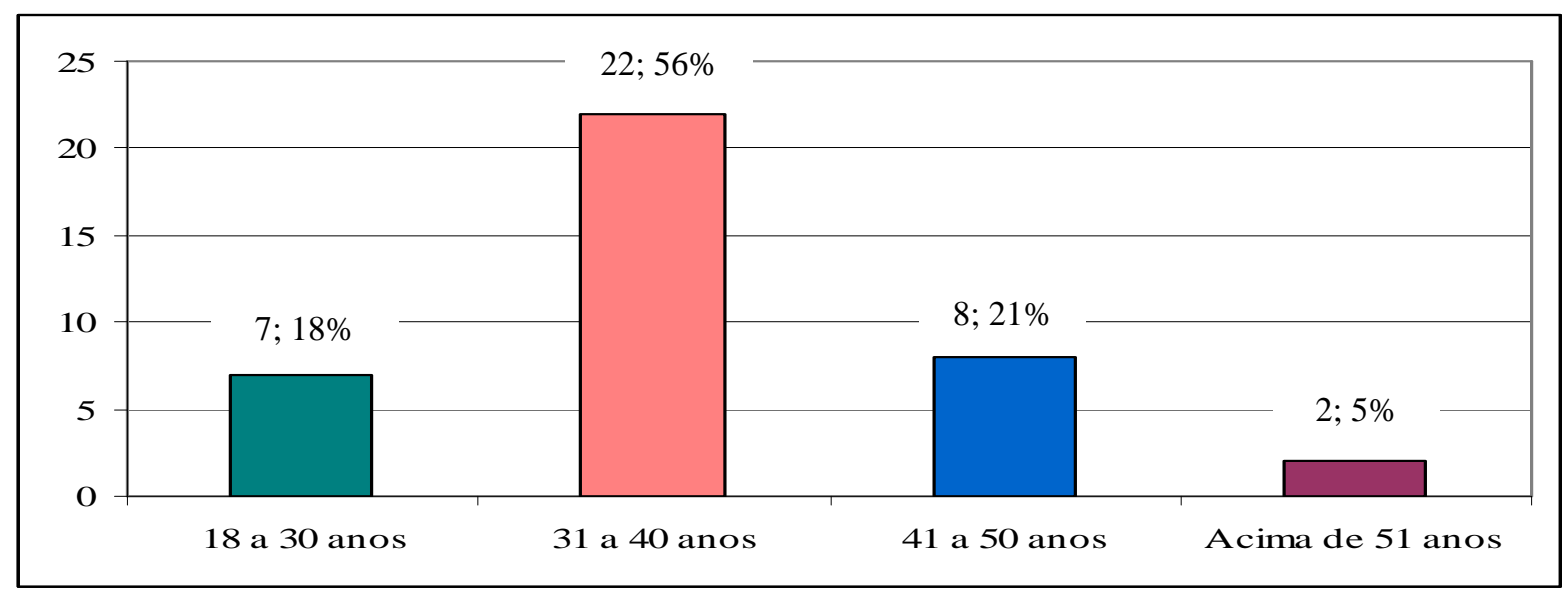

Figura 2 - Idade dos microempreendedores individuais em Nova Olímpia - MT, período de outubro/2011. FONTE: Dados da pesquisa.

Quanto à faixa etária pode-se afirmar que os microempreendedores individuais de $31 \mathrm{a}$ 40 anos são a maioria, os quais representam 56\% (cinquenta e seis por cento), $21 \%$ (vinte e um por cento) têm idade entre 41 a 50 anos, $18 \%$ (dezoito por cento) têm idade entre 18 a 30 anos, e apenas $5 \%$ (cinco por cento) têm idade acima de 51 anos.

Em relação ao nível de escolaridade dos empreendedores individuais em Nova Olímpia/MT, o gráfico a seguir apresenta os resultados obtidos através dos questionários aplicados. 


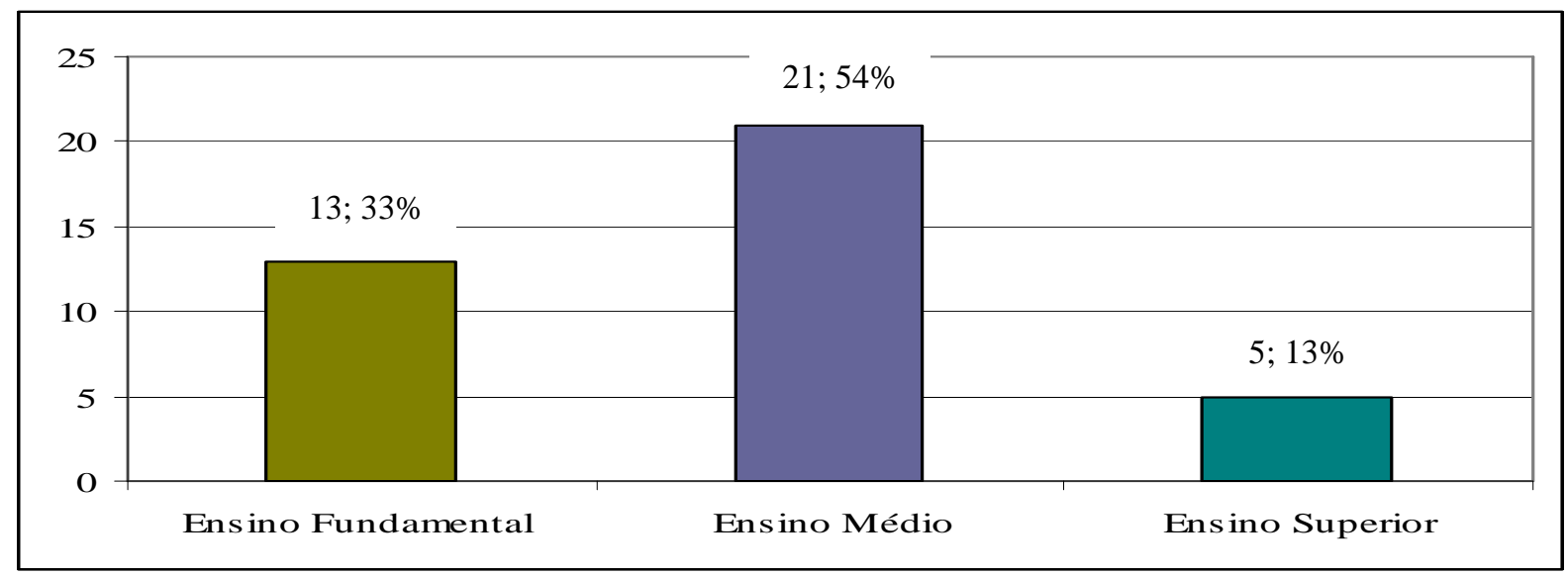

Figura 3 - Nível de escolaridade dos microempreendedores individuais em Nova Olímpia - MT, período de outubro/2011.

FONTE: Dados da pesquisa.

Na Figura 3, identifica-se os percentuais do nível de escolaridade dos entrevistados, onde $54 \%$ (cinquenta e quatro por cento) têm o ensino médio, 33\% (trinta e três por cento) têm o ensino fundamental e 13\% (treze por cento) têm o ensino superior.

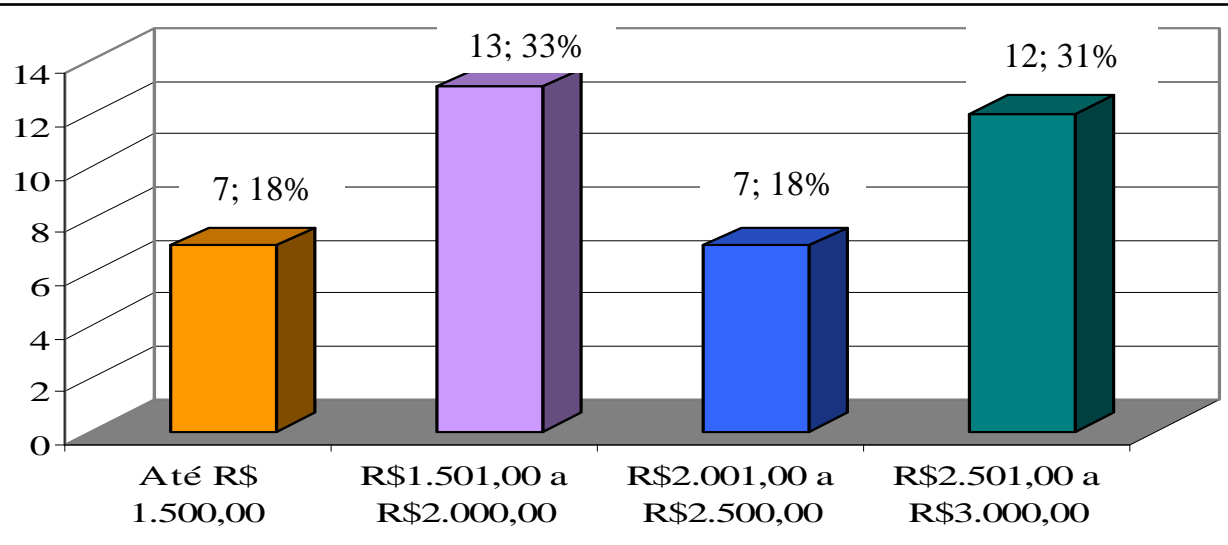

Figura 4 - Renda mensal dos microempreendedores individuais em Nova Olímpia - MT, período de outubro/2011.

FONTE: Dados da pesquisa.

A Lei Complementar 128/08 diz que para ser um Microempreendedor Individual tem que apresentar rendimentos de até $\mathrm{R} \$ 36.000,00$ (trinta e seis mil reais) anuais, ou seja, $\mathrm{R} \$$ 3.000,00 (três mil reais) mensais. Através da Figura 4 pode-se verificar que 33\% (trinta e três por cento) possuem renda mensal entre $\mathrm{R} \$ 1.501,00$ a $\mathrm{R} \$ 2.000,00$ (um mil quinhentos e um reais a dois mil reais), 31\% (trinta e um por cento) entre $\mathrm{R} \$ 2.501,00$ a $\mathrm{R} \$ 3.000,00$ (dois mil quinhentos e um reais a três mil reais), $18 \%$ (dezoito por cento) entre $\mathrm{R} \$ 2.001,00$ a $\mathrm{R} \$$ 2.500,00 (dois mil e um reais a dois mil e quinhentos reais) e 18\% (dezoito por cento) possuem renda de até $\mathrm{R} \$ 1.500,00$ (um mil e quinhentos reais), ou seja, nenhum dos entrevistados tem renda superior a $\mathrm{R} \$ 3.000,00$ (três mil reais). Desse modo, todos os 
entrevistados obedecem a este quesito estabelecido pela lei, que é a condição principal para ser um microempreendedor individual.

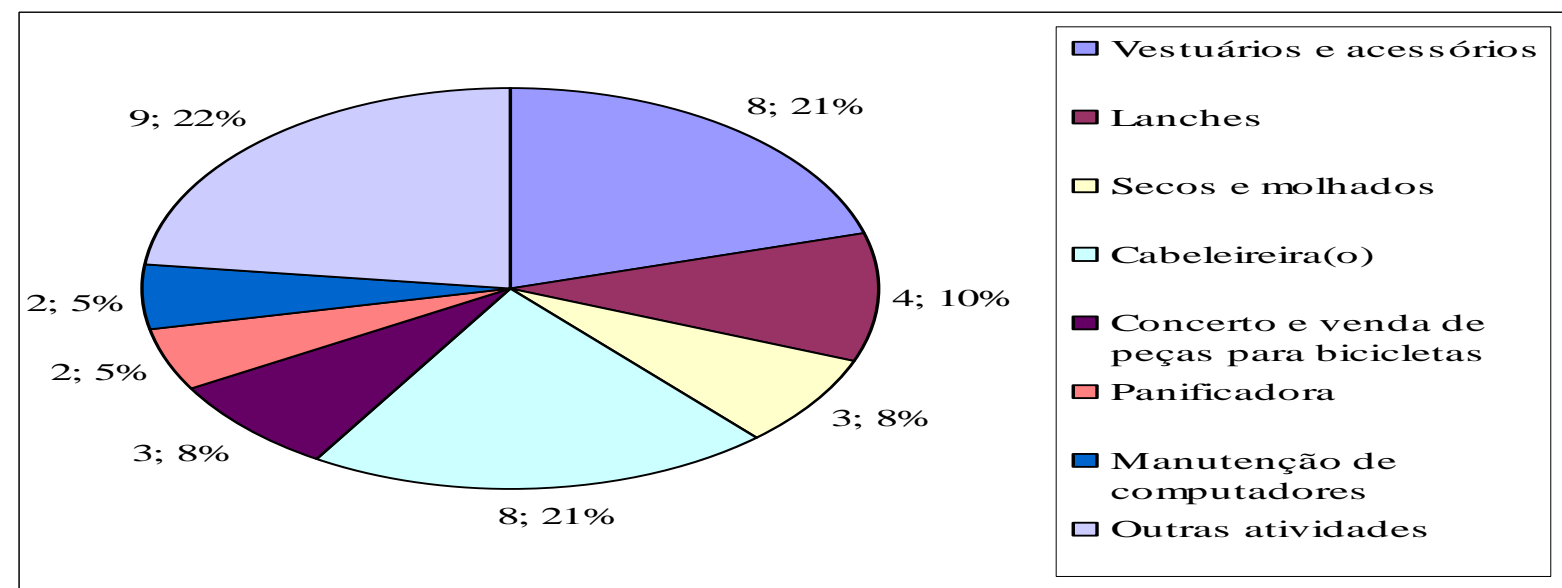

Figura 5 - Atividade principal exercida pelos microempreendedores individuais em Nova Olímpia - MT, período de outubro/2011.

FONTE: Dados da pesquisa.

No que se refere às atividades principais exercidas pelos microempreendedores individuais, foi observado através do questionamento que $21 \%$ (vinte e um por cento) se dedicam à venda de vestuário e acessórios, outros $21 \%$ (vinte e um por cento) são cabeleireiros (as), $10 \%$ (dez por cento) trabalham com a venda de lanches, $8 \%$ (oito por cento) trabalham com comércio de secos e molhados, ou seja, mercadinho, e 22\% (vinte e dois por cento) dos empreendedores exercem atividades variadas como: eletrônica, mecânica e manutenção elétrica de veículos, eletricista, costureira e sorveteria.

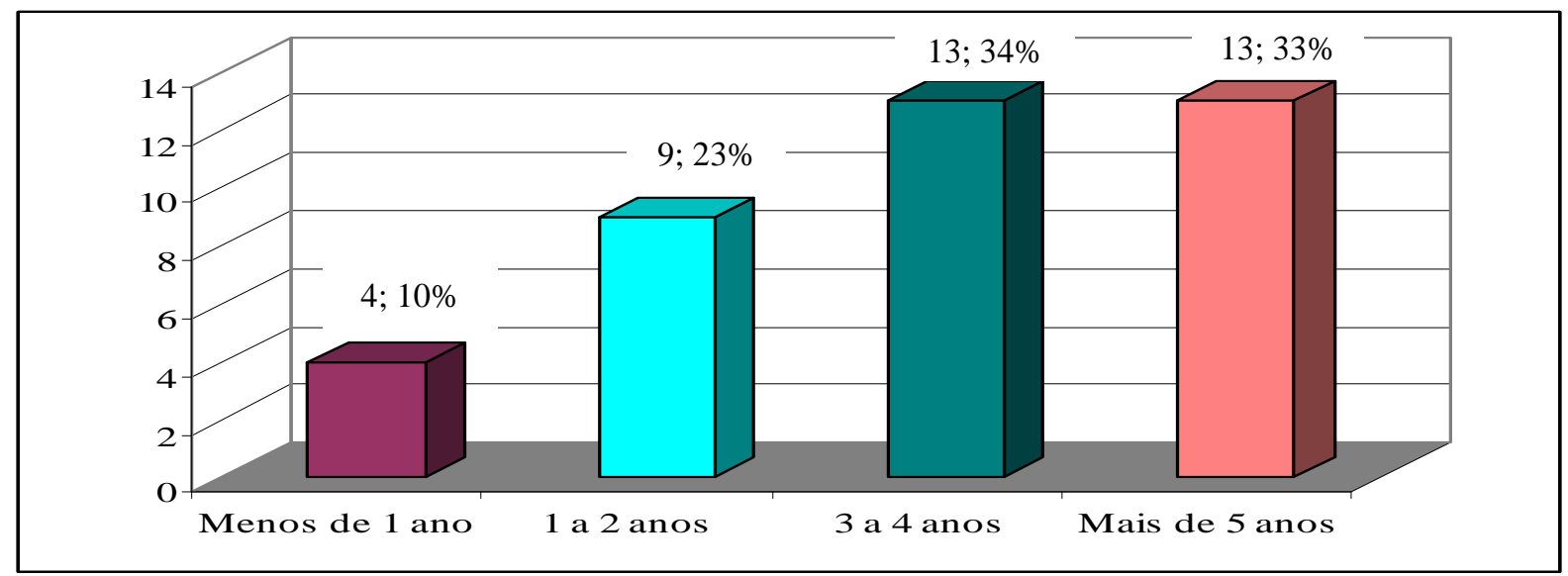

Figura 6 - Tempo de atuação e funcionamento do empreendimento dos microempreendedores individuais em Nova Olímpia - MT, período de outubro/2011.

FONTE: Dados da pesquisa.

Quanto ao tempo de atuação e funcionamento do empreendimento os resultados obtidos mostram que 34\% (trinta e quatro por cento) atuam entre 3 a 4 anos, 33\% (trinta três por cento) está em funcionamento a mais de 5 anos, o que significa que atuaram durante 
muito tempo na informalidade, $23 \%$ (vinte e três por cento) atuam entre 1 a 2 anos e $10 \%$ (dez por cento) a menos de 1 ano.

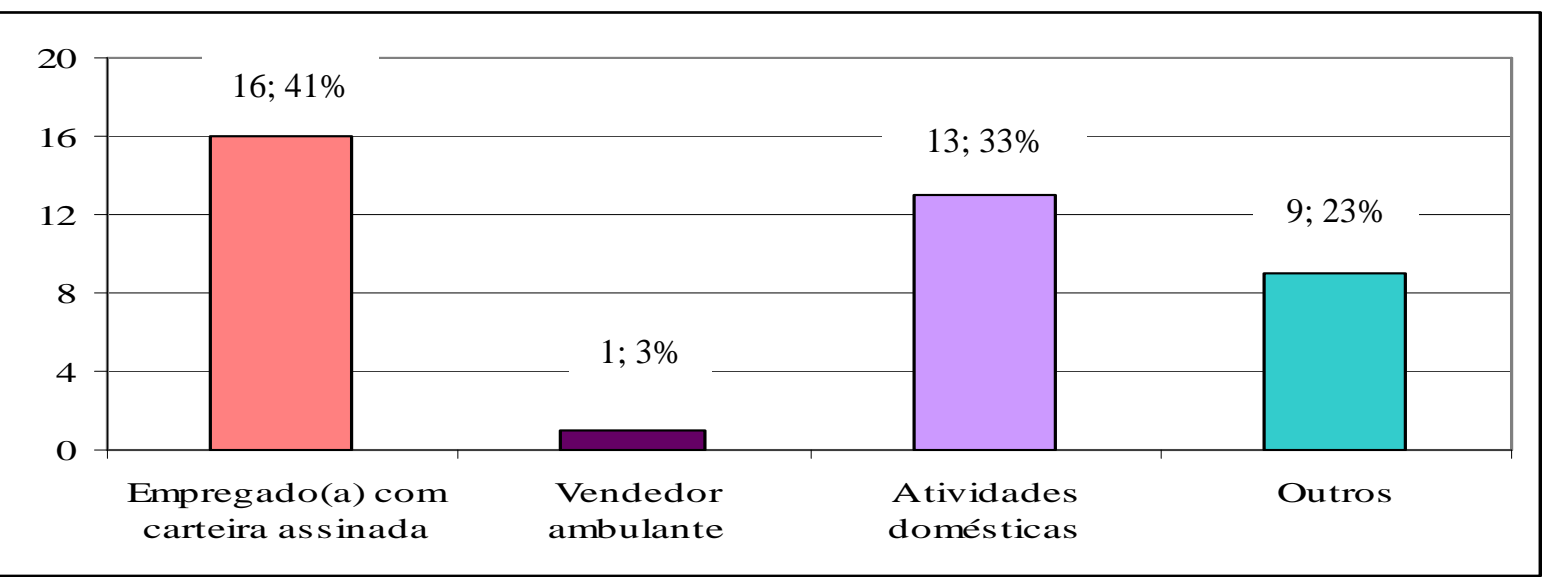

Figura 7 - Ocupação desempenhada pelos microempreendedores individuais em Nova Olímpia - MT antes de iniciar o empreendimento, período de outubro/2011.

FONTE: Dados da pesquisa.

Antes de iniciarem seus negócios os entrevistados exerciam outras funções dentre as quais $41 \%$ (quarenta e um por cento) eram empregados com registro em carteira, $33 \%$ (trinta e três por cento) exerciam atividades domésticas, $23 \%$ (vinte e três por cento) disseram que trabalhavam como autônomo, sendo motorista de caminhão, prestador de serviço, cabeleireiro(a) e costureira. E 3\% (três por cento) trabalhavam como vendedor ambulante.

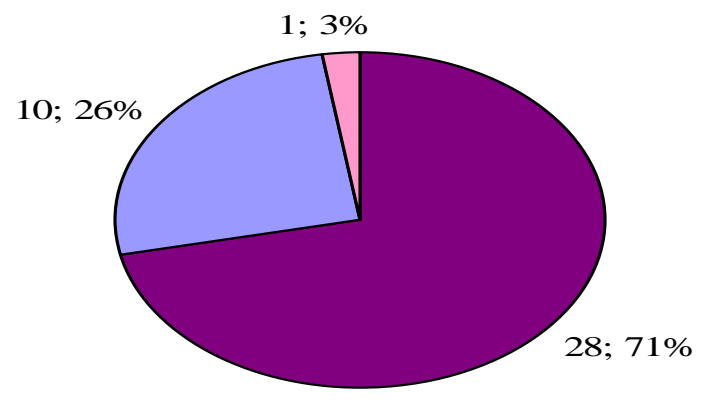

Própria/na residência $\square$ Alugada

$\square$ Ambulante/móvel

Figura 8 - Local de funcionamento dos microempreendedores individuais em Nova Olímpia - MT, período de outubro/2011.

FONTE: Dados da pesquisa.

Ao analisar a figura acima, acerca da localização do empreendimento, constatou-se que $71 \%$ (setenta e um por cento por cento) estão localizados em imóvel próprio ou na residência, 26\% (vinte e seis por cento) funcionam em imóvel alugado e 3\% (três por cento) são ambulante ou móvel, ou seja, funcionam em local fixo só que ao final do dia recolhem seus materiais de trabalho. 


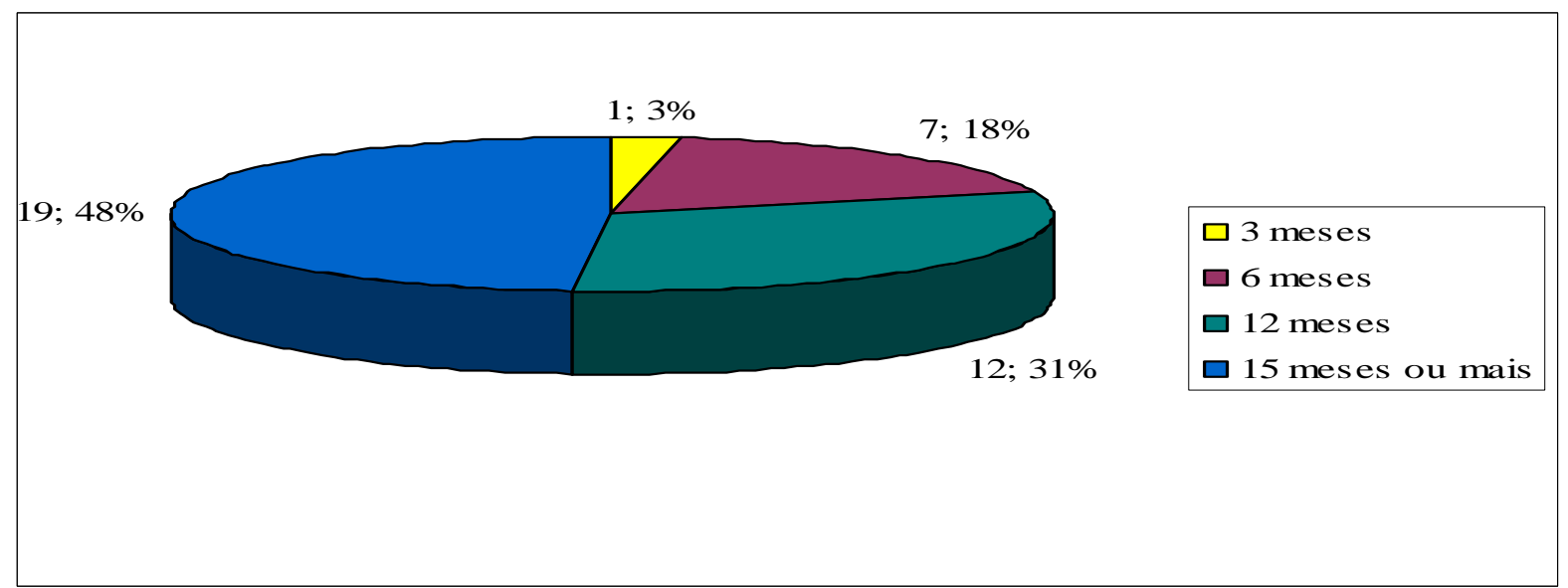

Figura 9 - Há quanto tempo os microempreendedores individuais de Nova Olímpia - MT, são formalizados como MEI, período de outubro/2011.

FONTE: Dados da pesquisa.

Quanto à questão da pesquisa que procurou saber acerca do tempo de formalização, foi constatado que $48 \%$ (quarenta e oito por cento) são formalizados como microempreendedores individuais a 15 (quinze) meses ou mais, 31\% (trinta e um por cento) são formalizados a 12 (doze) meses, $18 \%$ (dezoito por cento) a 6 (seis) meses e $3 \%$ (três por cento) a 3 (três) meses.

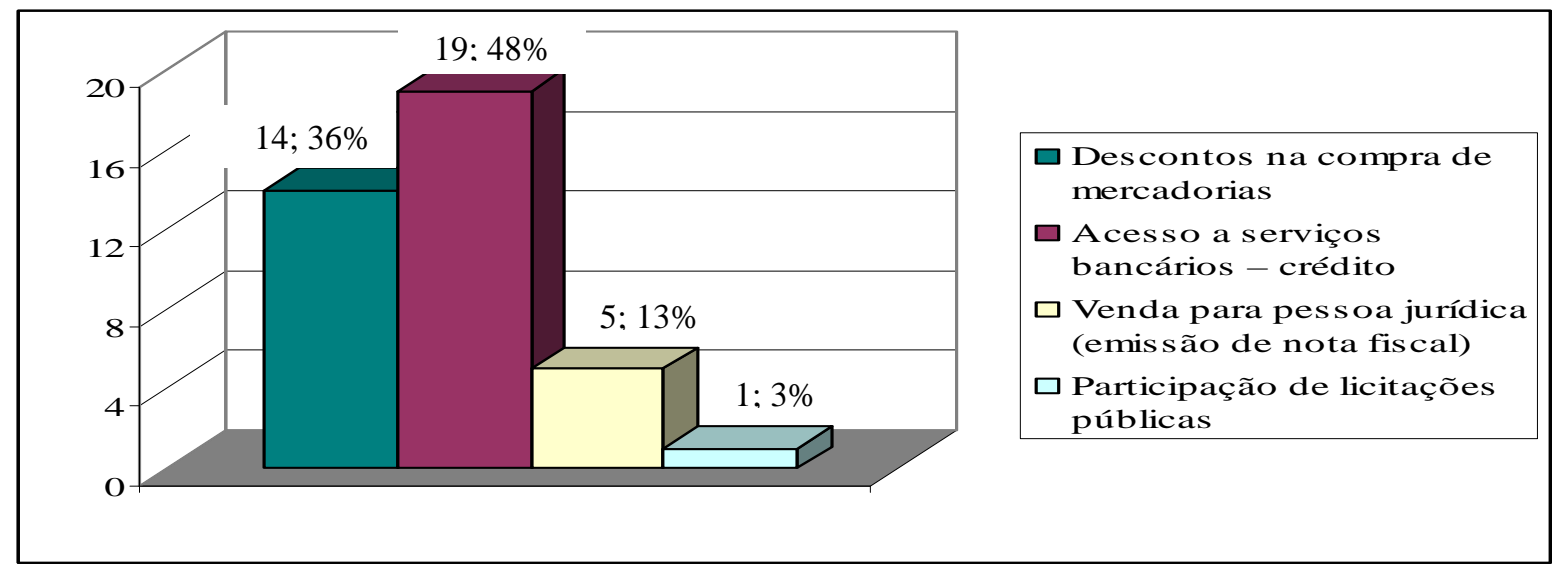

Figura 10 - Benefícios identificados após a formalização como microempreendedores individuais em Nova Olímpia - MT, período de outubro/2011.

FONTE: Dados da pesquisa.

Foi questionado aos microempreendedores individuais sobre os benefícios identificados na execução da atividade após a formalização como MEI, 48\% (quarenta e oito por cento) indicaram o acesso a serviços bancários - crédito como o principal benefício, pois através dele puderam ampliar seus investimentos no negócio e assim aumentar as vendas, $36 \%$ (trinta e seis por cento) disseram que obtiveram descontos na compra de mercadorias após se tornarem pessoa jurídica, pois antes compravam como pessoa física e o custo da mercadoria era maior, $13 \%$ (treze por cento) disseram ser a venda para pessoas jurídicas, ou seja, a possibilidade de emissão de nota fiscal e 3\% (três por cento) indicaram a participação em licitação pública. 


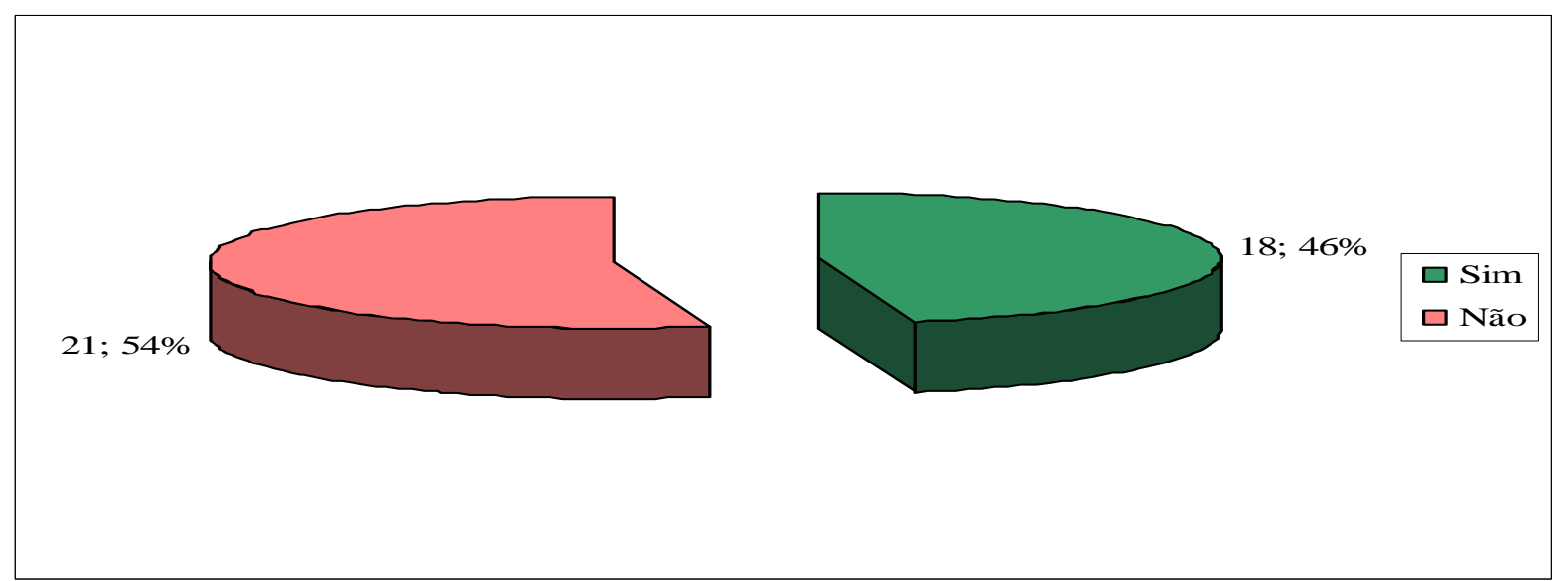

Figura 11 - Microempreendedores individuais de Nova Olímpia - MT, que contam com assessoria de profissional contábil, período de outubro/2011.

FONTE: Dados da pesquisa.

Os microempreendedores individuais estão dispensados de contabilidade, no entanto, eles podem contar com a assessoria de profissional contábil para auxiliá-lo e orientá-lo no seu pequeno negócio, principalmente se este empreendedor contratar empregado para auxiliá-lo na atividade, o que indica custo extra pelo serviço adquirido.

Dentre os entrevistados $54 \%$ (cinquenta e quatro por cento) não contam com a assessoria de profissional contábil e $46 \%$ (quarenta e seis por cento) dizem ter esta assessoria para auxiliá-lo na emissão da declaração anual do MEI e também na elaboração dos relatórios mensais de receita bruta, documentação para abertura de conta bancária e serviços mensais referentes a contratação de empregado.

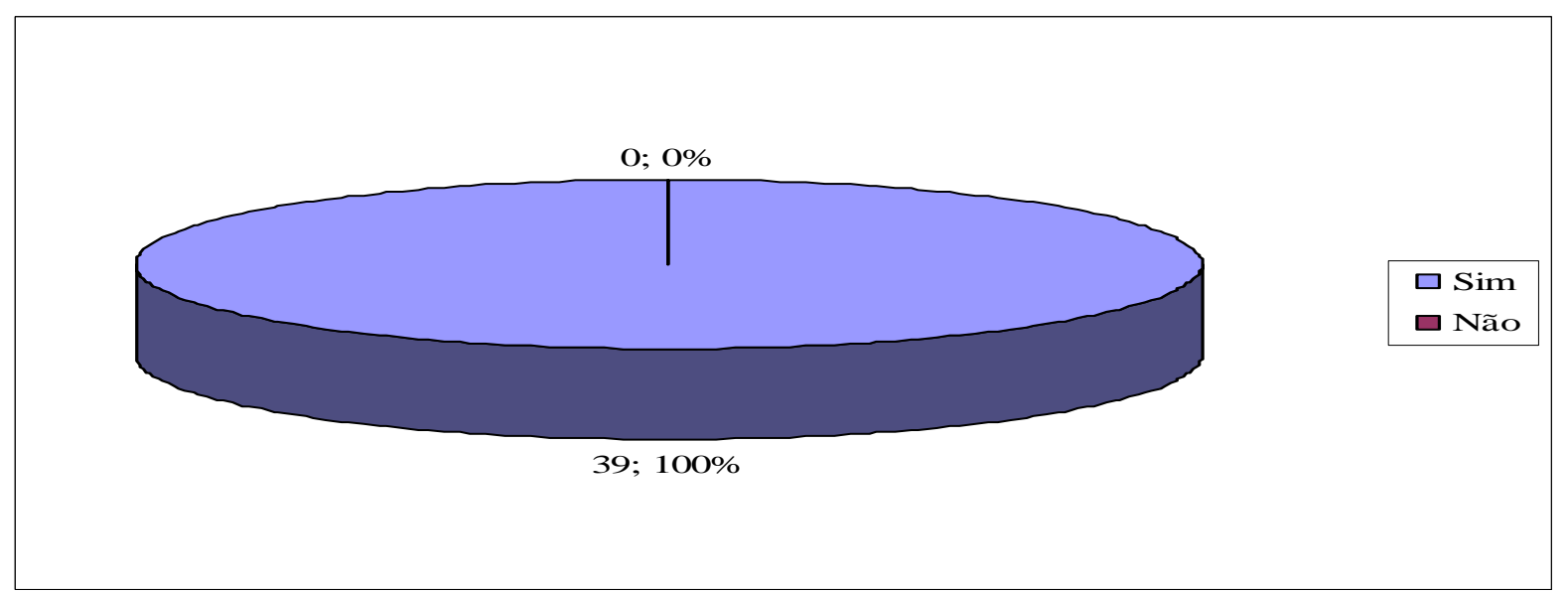

Figura 12 - Microempreendedores individuais de Nova Olímpia - MT, que consideram que a formalização como MEI é alternativa desburocratizante para os pequenos negócios crescerem e se desenvolverem, período de outubro/2011.

FONTE: Dados da pesquisa.

A Lei Complementar 128/08 surgiu como incentivo para que os pequenos negócios, ou seja, trabalhadores autônomos e/ou por conta própria se desenvolverem e ampliarem seus negócios, através dos benefícios elencados a formalização como MEI. 
Foi questionado aos microempreendedores individuais se eles acreditam que a formalização é alternativa desburocratizante para o crescimento e desenvolvimento dos pequenos negócios, e constatou-se que $100 \%$ (cem por cento) dos entrevistados afirmaram que acreditam que com a legalização como MEI os pequenos negócios tendem a crescer e a se desenvolver e até se tornarem microempresas futuramente. Pois é alternativa desburocratizante para o exercício de pequenos negócios, iniciando pela praticidade de se formalizar e também pelo baixo custo de manter o empreendimento regularizado.

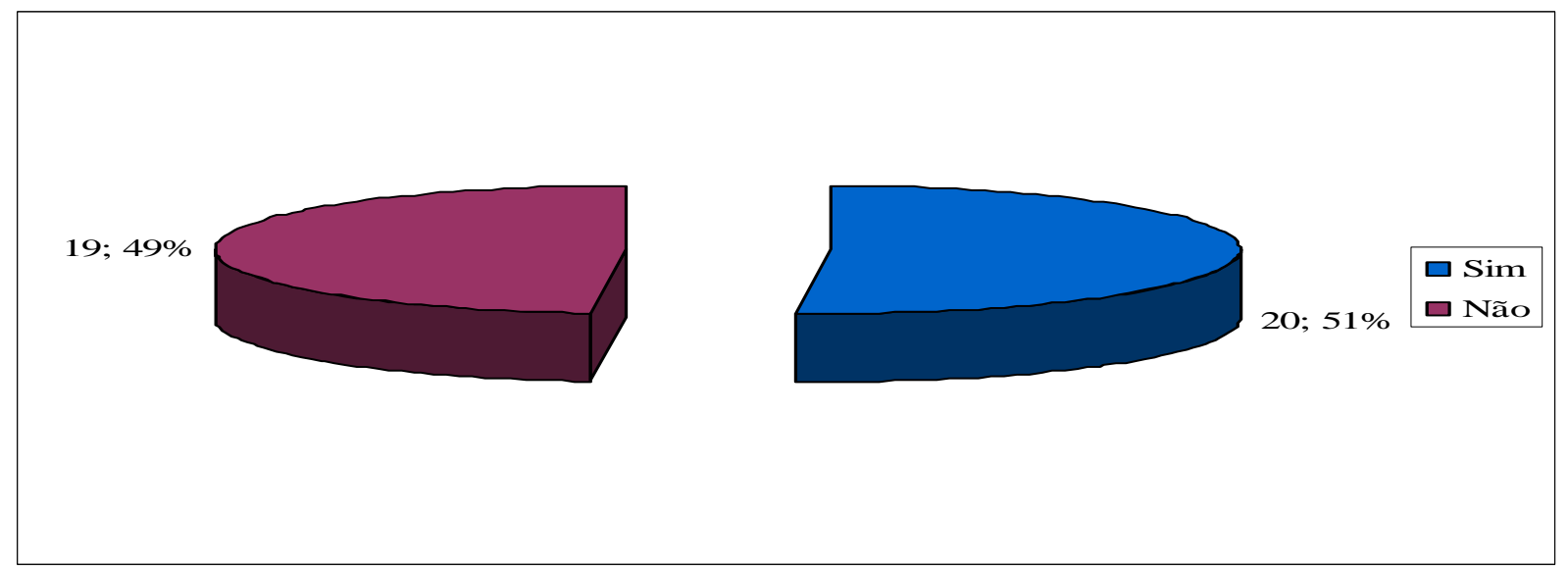

Figura 13 - Microempreendedores individuais de Nova Olímpia - MT, que possuem colaboradores na execução na atividade, período de outubro/2011.

FONTE: Dados da pesquisa.

Dentre os microempreendedores individuais entrevistados, $51 \%$ (cinquenta e um por cento) afirmam ter um colaborador que o auxilia na execução da atividade e 49\% (quarenta e nove por cento) não tem colaborador, ou seja, trabalham sozinhos.

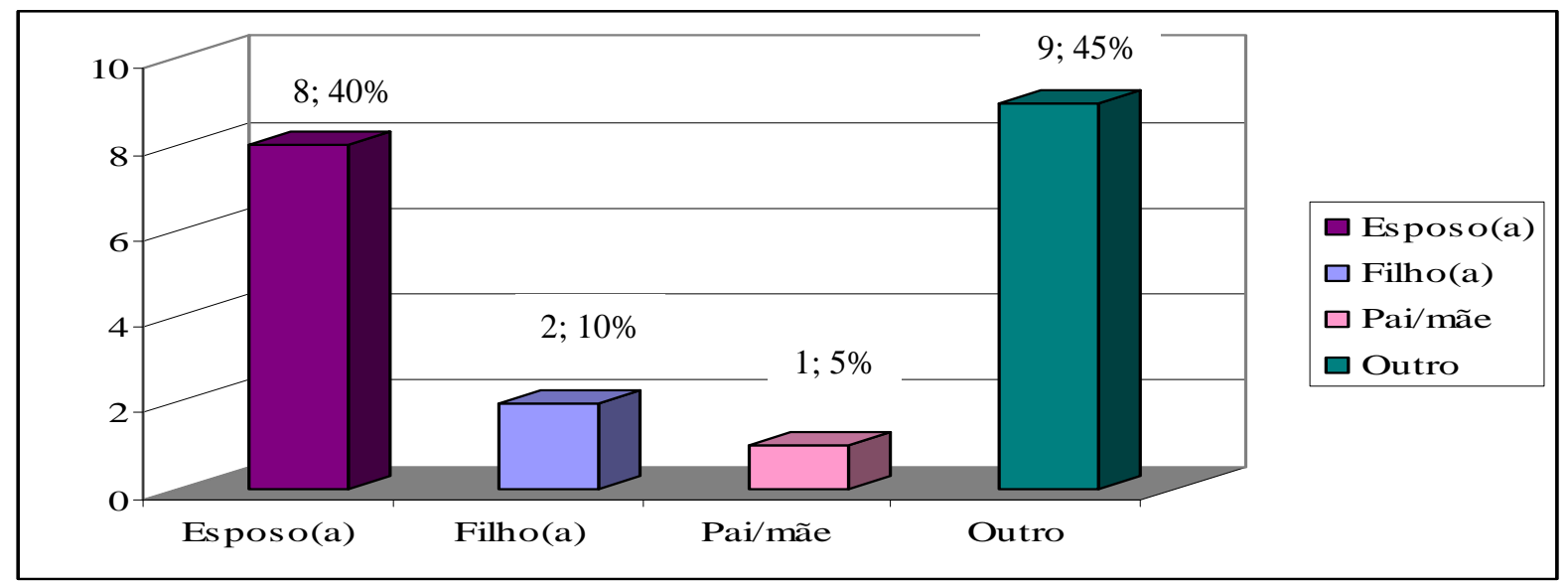

Figura 14 - Microempreendedores individuais de Nova Olímpia - MT, que tem como colaborador parente e/ou familiar, período de outubro/2011.

FONTE: Dados da pesquisa.

Na figura 14, demonstra a classificação do colaborador do MEI quanto ao grau de parentesco. Dentre os entrevistados que contam com auxílio de colaborador, $45 \%$ (quarenta e cinco por cento) disseram que não tem como colaborador um parente e/ou familiar, mas sim 
um amigo e/ou conhecido, 55\% (cinquenta e cinco por cento) contam com a colaboração de parente e/ou familiar, sendo o esposo(a), o filho(a) e pai/mãe. Portanto, a maioria dos estabelecimentos que possuem colaborador é de característica familiar, ou seja, os próprios membros da família administram o negócio.

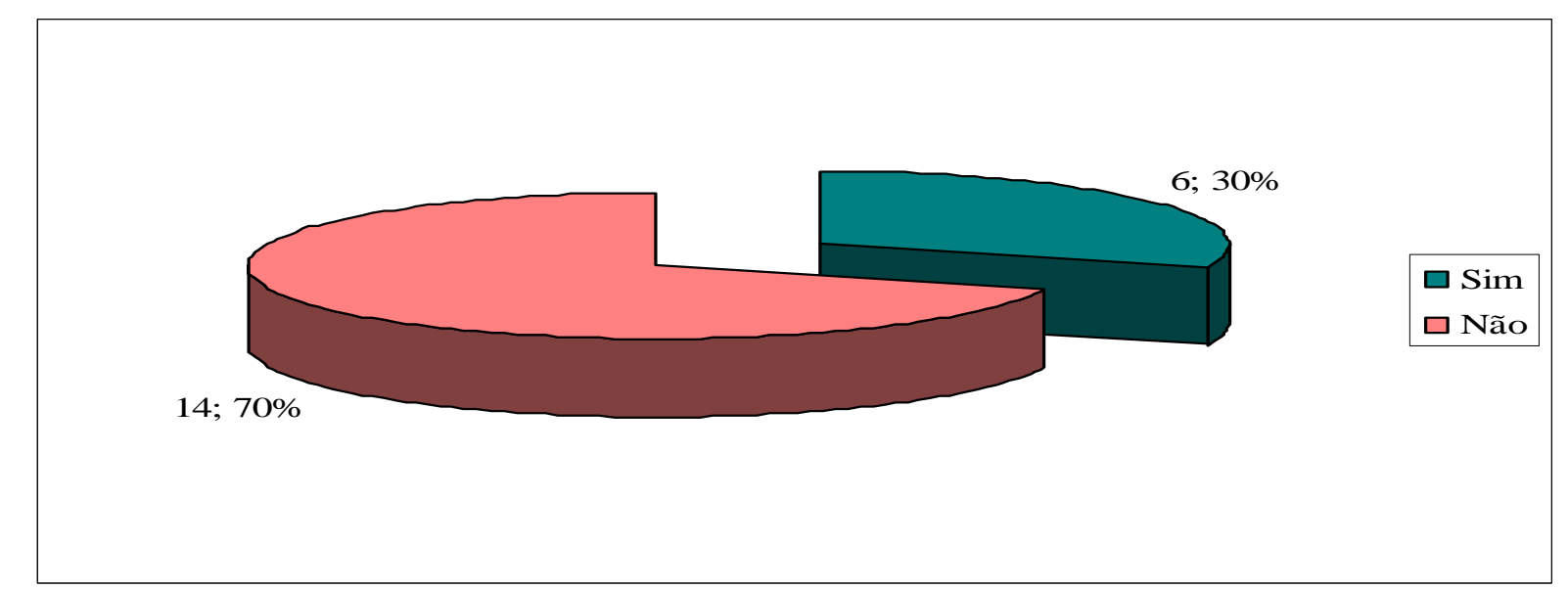

Figura 15 - Microempreendedores individuais que possuem colaborador com registro em carteira em Nova Olímpia - MT, período de outubro/2011.

FONTE: Dados da pesquisa.

Constatou-se que apenas 30\% (trinta por cento) dos microempreendedores individuais têm colaborador com carteira registrada e $70 \%$ (setenta por cento por cento) dos entrevistados não registraram a carteira do seu colaborador.

\section{CONSIDERAÇÕES FINAIS}

A princípio, o intuito da Lei Complementar 128/08 que criou a figura jurídica do MEI, é minimizar ao máximo a informalidade no país e garantir direitos e benefícios que antes como trabalhador informal não havia possibilidade de ter. Com a carga tributária reduzida, ausência de burocracia, isenção de taxas para regularização do negócio, entre outros benefícios, procura oportunizar a possibilidade de crescimento e desenvolvimento dos pequenos negócios.

A situação problema mencionada neste trabalho, consiste em responder quais os reflexos da formalização do microempreendedor individual para o desenvolvimento dos pequenos negócios. Por meio dos dados coletados, verificou-se sob a ótica dos entrevistados, que ser um microempreendedor individual é oportunidade de crescimento e desenvolvimento, eles vêem a chance de crescer no mercado, pois $100 \%$ (cem por cento) dos empreendedores afirmam conforme Figura 12, que com a regularização os pequenos negócios tendem a crescer, se desenvolver e posteriormente se tornarem uma microempresa. 
A hipótese levantada para responder ao problema, foi confirmada, como mostra a Figura 12, pois a figura jurídica do MEI é alternativa desburocratizante para a regularização e exercício dos pequenos negócios, iniciando pela praticidade de se formalizar e também pelo baixo custo de manter o empreendimento regularizado.

Em relação ao objetivo geral da pesquisa que era averiguar a adesão do Microempreendedor Individual no município de Nova Olímpia/MT, e quais benefícios o reflexo da formalização lhes trará, o mesmo foi atendido porque foram constatados 39 (trinta e nove) microempreendedores formalizados no município, sendo que $48 \%$ (quarenta e oito por cento) deles estão regularizados a 15 (quinze) meses ou mais. Conforme Figura 10, dentre os benefícios elencados ao MEI, 48\% (quarenta e oito por cento) indicaram o acesso a serviços bancários, ou seja, acesso ao crédito como o principal benefício na execução da atividade após a formalização, pois através deste puderam aumentar o investimento no seu negócio. Outros $36 \%$ (trinta e seis por cento) destacaram os descontos na compra de mercadorias após se tornarem pessoa jurídica.

Os reflexos da formalização têm sido favoráveis para os empreendedores individuais, além da contribuição ao desenvolvimento do seu negócio, tem o benefício social que a Lei proporciona que é garantir o direito a aposentadoria, assim como também o auxílio doença, auxílio reclusão e salário maternidade, que beneficiam tanto o empreendedor como seus familiares.

Quanto aos objetivos específicos, foi possível identificar o perfil socioeconômico dos microempreendedores individuais atuantes no município de Nova Olímpia/MT. Dentre os 39 (trinta e nove) empreendedores, verificou-se que 56\% (cinquenta e seis por cento) são do sexo feminino, como mostra a Figura 1; quanto à faixa etária 56\% (cinquenta e seis por cento) têm idade entre 31 a 40 anos, conforme Figura 2; 54\% (cinquenta e um por cento) têm o ensino médio, segundo Figura 3; 33\% (trinta e três por cento) têm renda mensal entre R $\$ 1.501,00$ a $\mathrm{R} \$ 2.000,00$ (um mil quinhentos e um reais a dois mil reais), como demonstra a Figura 4. Quanto aos empreendimentos em que atuam, constatou-se que dentre as atividades principais encontradas, destaca-se o comércio de vestuário e acessórios com 21\% (vinte e um por cento), outros $21 \%$ (vinte e um por cento) são cabeleireiros (as), e 22\% (vinte e dois por cento) dos empreendedores exercem atividades variadas como: eletrônica, mecânica e manutenção elétrica de veículos, eletricista, costureira e sorveteria. 
Sabendo-se que o MEI pode contratar 01 (um) empregado que receba o salário mínimo ou piso da categoria, constatou-se que $51 \%$ (cinquenta e um por cento) contam com o auxílio de 01 (um) colaborador na execução das suas atividades, dentre os colaboradores 55\% (cinquenta e cinco por cento) são membros da família, ou seja, esposo(a), filho(a), pai/mãe, caracterizando um empreendimento familiar. No entanto, apenas 30\% (trinta por cento) dos empreendedores efetivaram o registro em carteira de seus colaboradores.

Com o intuitivo de incentivar a regulamentação de mais empreendedores, o governo federal através da Medida Provisória 529, que foi convertida na Lei 12.470 reduziu a alíquota de contribuição à previdência social, que era de $11 \%$ (onze por cento) para $5 \%$ (cinco por cento) sobre o salário mínimo, que equivale a $\mathrm{R} \$ 27,25$ (vinte e sete reais e vinte e cinco centavos), a contribuição total a pagar se o empreendedor exercer atividades de comércio e serviços é de $\mathrm{R} \$ 33,25$ (trinta e três reais e vinte e cinco centavos). Assim como também, o aumento da receita bruta anual que era de $\mathrm{R} \$ 36.000,00$ (trinta e seis mil reais) para $\mathrm{R} \$$ $60.000,00$ (sessenta mil reais) anuais, ou seja, $\mathrm{R} \$ 5.000,00$ (cinco mil reais) mensais, que representa um aumento no faturamento em média de $60 \%$ (sessenta por cento).

No país, a meta estabelecida pelo governo federal e pelas instituições de apoio a formalização para 2011 era de 1,5 milhão de microempreendedores individuais formalizados. Essa meta já foi alcançada antes mesmo de terminar o ano, isso significa que as formalizações avançam em todo o país e cada vez mais trabalhadores estão buscando sair da informalidade, que através da legalização de suas atividades possibilita fomentar o desenvolvimento econômico nacional, com a geração de emprego e renda.

Para efeitos de arrecadação tributária para o município a quantia ainda é insignificante, visto que a quantidade de microempreendedores formalizados é pequena, o qual representa aproximadamente $15 \%$ (quinze por cento) dos 262 (duzentos e sessenta e dois) trabalhadores que atuam de maneira informal em Nova Olímpia/MT. No entanto, os benefícios poderão ser percebidos no longo prazo, pois conforme a adesão ao MEI for aumentando e esses pequenos negócios forem desenvolvendo e crescendo, poderão mudar sua estrutura jurídica, se enquadrando em outras formas jurídicas no qual poderão aumentar a sua tributação e, consequentemente, aumentando a arrecadação tributária e trazendo benefícios econômicos para o município. 


\section{REFERÊNCIAS BIBLIOGRÁFICAS}

BEUREN, Ilse Maria. (Coord). Como Elaborar Trabalhos Monográficos em

Contabilidade - Teoria e Prática. 2.ed. São Paulo: Atlas, 2004.

BOTH, Sérgio José. SIQUEIRA, Claudineide J. de Souza. Metodologia Científica: faça fácil a sua pesquisa. Tangará da Serra, MT: Editora São Francisco, 2004.

BRASIL, Ministério da Fazenda. Simples Nacional. Roteiro para o Microempreendedor Individual (MEI). Brasília, 2008. Disponível em:

<http://www8.receita.fazenda.gov.br/SimplesNacional/noticias/2009/outubro/Roteiro_para_M icroempreendedor_Individual_MEI.asp >. Acesso em 30 Abr. 2011.

, Ministério do Desenvolvimento, Indústria e Comércio Exterior. Portal do

Empreendedor. Brasília, 2009. Disponível em: 〈http://www.portaldoempreendedor.gov.br〉. Acesso em 22 Abr. 2011.

, Receita Federal. MP 529 diminui carga tributária do Microempreendedor

Individual. Acessória de Comunicação - Ascom. Brasília, 2011. Disponível em:

$<$ http://www.receita.fazenda.gov.br/AutomaticoSRFsinot/2011/04/08/2011_04_08_12_52_52 _773782565.html>. Acesso em 30 Abr. 2011.

CACCIAMALI, Maria Cristina. Globalização e processo de informalidade. Revista Economia e Sociedade - p. 153-174. Campinas, 2000. Disponível em:

<http://www.eco.unicamp.br/docdownload/publicacoes/instituto/revistas/economia-esociedade/V9-F1-S14/06-Cacciamali.pdf>. Acesso em: 03 Mar. 2011.

CHIAVENATO, Idalberto. Empreendedorismo: dando asas ao espírito empreendedor. São Paulo: Saraiva, 2006.

CONSELHO REGIONAL DE CONTABILIDADE DE MATO GROSSO (CRC-MT).

Empreendedor: declaração anual do Simples Nacional será suspensa. Cuiabá, 2011.

Disponível em: http://www.crcmt.org.br/site/novo/index.php?act=vernoticias\&id=3364>

Acesso em: 01 set. 2011

FERNANDES, Jean Carlos. MACIEL, Luciana Botelho. SOSSAI, Henrique Matheus

Mariani. O Microempreendedor Individual (MEI): vantagens e desvantagens do novo sistema. Belo Horizonte, 2011. Disponível em:

$\langle$ http://direito.newtonpaiva.br/revistadireito/docs/prof/16_ProfJeanCarlosFernandes.pdf $>$.

Acesso em 03 Mar. 2011.

GIL, Antonio Carlos. Como elaborar projetos de pesquisa. 5 ed. São Paulo: Atlas, 2010.

HIRATA, Guilherme Issamu. A economia informal no Brasil: aspectos de inserção permanência e transição no mercado de trabalho metropolitano. Dissertação (Mestrado em Economia) - Centro de Desenvolvimento e Planejamento Regional da Faculdade de Ciência Econômicas da universidade Federal de Minas Gerais. Belo Horizonte, 2007. Disponível em: <http://www.dominiopublico.gov.br/pesquisa/DetalheObraDownload.do?select_action=\&co obra=92244\&co_midia=2 >. Acesso em: 15 Abr. 2011.

IBGE, Instituto Brasileiro de Geografia e Estatística. Brasil tem mais de 10 milhões de empresa na informalidade - Comunicação Social 19 de maio de 2005. Disponível em:> http://www.ibge.gov.br/home/presidencia/noticias/noticia_visualiza.php?id_noticia=366\&id pagina=1>. Acesso em 22 Abr. 2011.

OLIVEIRA, Antonio Benedito Silva. (Coord). Métodos de pesquisa em contabilidade. São Paulo: Saraiva, 2003. 
OLIVEIRA, Silvio Luiz de. Tratado de Metodologia Científica: projetos de pesquisas, TCI, TCC, monografias, dissertações e teses. São Paulo: Pioneira Thomson Learning, 2011.

SANTOS. Jefferson Dias. FREITAS, Ricardo Costa. O "Microempreendedor Individual" um passo positivo para a economia brasileira. Juiz de Fora/MG, 2009. Disponível em: <http://www.biblioteca.sebrae.com.br/bds/BDS.nsf/d086c43daf01071b03256ebe004897a0/17 b19cb657e41c018325756d0082a5b2/\$FILE/NT0003DE42.pdf>. Acesso em 03 Mar. 2011.

SERVIÇO BRASILEIRO DE APOIO ÁS MICRO E PEQUENAS EM EMPRESAS SEBRAE. Agência Sebrae de notícias. Projeto que altera Supersimples pode ser votado na terça. Brasília, 2011. Disponível em:

$<$ http://www.agenciasebrae.com.br/noticia/12406702/politicas-publicas/projeto-que-alterasupersimples-pode-ser-votado-na-terca/>. Acesso em: 16 set. 2011.

SERVIÇO BRASILEIRO DE APOIO ÁS MICRO E PEQUENAS EM EMPRESAS SEBRAE. Sebrae MG com você. Brasil já tem 1,5 milhão de empreendedores individuais. Belo Horizonte, 2011. Disponível em:

<http://sebraemgcomvoce.wordpress.com/2011/09/12/brasil-ja-tem-15-milhao-deempreendedores-individuais/ >. Acesso em: 07 Out. 2011.

SECRETARIA DE ESTADO E PLANEJAMENTO E COORDENAÇÃO GERAL-SEPLAN. Superintendência de Estudos e Informações. Censo Econômico de Nova Olímpia. Cuiabá, 2006. Disponível em: www.indicador.seplan.mt.gov.br/censo/. Acesso em 22 Mai. 2011.

SILVA, Alessandra Brasiliano da. LOPES, José Expedito de Gusmão. FILHO, José Francisco Ribeiro. et al. Um estudo sobre a percepção dos empreendedores individuais da cidade de Recife quanto à adesão a lei do micro empreendedor individual (lei mei - 128/08). Revista da Micro e Pequena Empresa. Faculdade Campo Limpo Paulista - FACAMP. V.4, n.3 (2010) Set/Dez. p 121-137. Disponível em:

<http://www.faccamp.br/ojs/index.php/RMPE/article/view/183vv>. Acesso em: 01 set. 2011.

SILVA, Adriana Dias. Informalidade: comportamento do setor informal em Anápolis/GO (1986-2002). Dissertação (Mestrado em Sociologia) - Universidade Federal de Goiás Faculdade de Ciências Humanas e Filosofia. Goiânia, 2002. Disponível em:

<http://www.dominiopublico.gov.br/pesquisa/DetalheObraForm.do?select_action=\&co_obra $=129360>$. Acesso em: 15 Abr. 2011.

SILVA, Adriana Fontes Rocha Expósito da. Ensaios sobre informalidade no Brasil. Tese (Doutorado em Economia) - Instituto de Economia, Universidade Federal do Rio de Janeiro, Rio de Janeiro, 2009. Disponível em:

<http://www.dominiopublico.gov.br/pesquisa/DetalheObraForm.do?select_action=\&co_obra $=171533>$. Acesso em: 15 Abr. 2011.

SILVA, Mariana Passos Costa. Caminhos alternativos: empreendedorismo, informalidade e inclusão social. Dissertação (Mestrado em Políticas Sociais) - Universidade Estadual do Norte Fluminense. Campos dos Goytacazes, 2008. Disponível em:

$<$ http://www.dominiopublico.gov.br/pesquisa/DetalheObraForm.do?select_action=\&co_obra =179093 >. Acesso em: 03 Mar.2011.

THEODORO, Mário. As Bases da Política de Apoio ao Setor Informal. Texto para discussão nº. 762. IPEA - Instituto de Pesquisa Econômica Aplicada. Brasília, 2000. Disponível em:

$<$ http://scholar.google.com.br/scholar?q=As+Bases+da+Pol\%C3\%ADtica+de+Apoio+ao+Set or+Informal+no+Brasil\&hl=pt-BR\&btnG=Pesquisar\&lr=> . Acesso em: 03 Mar.2011. 
VERGARA, Sylvia Constant. Projetos e relatórios de pesquisa em administração. São Paulo: Atlas, 1997.

VIANNA, Márcia Coelho de Segadas. A Discussão Histórica da Informalidade: significados e formas de representação. Tese (Doutor em Ciências Humanas: Sociologia) Instituto Universitário de Pesquisas do Rio de Janeiro. Rio de Janeiro, 2006. Disponível em: <http://www.dominiopublico.gov.br/pesquisa/DetalheObraForm.do?select_action=\&co_obra =29180>. Acesso em: 03 Mar.2011. 